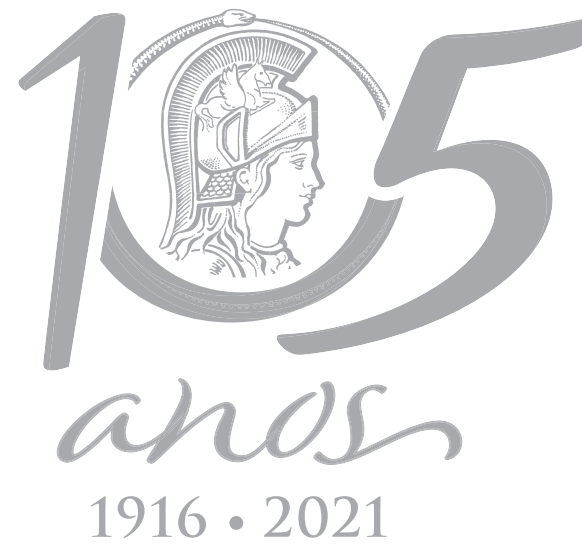

$1916 \cdot 2021$

\title{
ECOSYSTEMS
}

\section{Parasites in Leporinus macrocephalus (Anostomidae) of four fish farms from the western Amazon (Brazil)}

\author{
LUCIANO P. NEGREIROS, LIGIA R. NEVES \& MARCOS TAVARES-DIAS
}

\begin{abstract}
This study evaluated the presence of metazoan parasites in Leporinus macrocephalus from four fish farms from the western Amazon (Brazil). In 160 fish examined, prevalence was $61.9 \%$, and parasites found were: Urocleidoides paradoxus, Urocleidoides eremitus, Tereancistrum parvus, Jainus leporini, Procamallanus (Spirocamallanus) inopinatus, Rhabdochona (Rhabdochona) acuminata, Dolops discoidalis and Ergasilus sp., but U. paradoxus was the dominant parasite. Jainus leporini and Ergasilus sp. occurred only in L. macrocephalus from one fish farm, while $U$. paradoxus, U. eremitus and T. parvus were found in fish from three fish farms. Dolops discoidalis, P. (S.) inopinatus and R. (R.) acuminata occurred only in L. macrocephalus from two fish farms. Higher infection levels were caused by $U$. paradoxus, U. eremitus and P. (S.) inopinatus, which had an aggregated dispersion. There was positive correlation between abundance of parasites and the length of hosts. No difference in the condition factor of parasitized and non-parasitized fish were found. Such differences between fish farms were attributed to differences in management and quality of cultivation environments, and data indicate the need to adopt prophylactic measures in the fish farms to prevent diseases in the future. This was the first report of $D$. discoidalis and Ergasilus sp. for L. macrocephalus.
\end{abstract}

Key words: Dolops discoidalis, Ergasilus sp., freshwater fish, prevalence, Urocleidoides paradoxus.

\section{INTRODUCTION}

Leporinus macrocephalus Garavello \& Britski, 1988; popularly known as piauçu or piavussu, is an endemic Anostomidae fish to the Paraguay River basin and can reach up to $60 \mathrm{~cm}$ in length; hence it is an important fishery resource and also valuable for aquaculture of some Brazilian regions. Among the species of the genus Leporinus, L. macrocephalus is the largest species. Thus, it had been cultivated mainly in the Southeast Brazilian region, once it presents high weight gain, high feed conversion, fast growth, tasty meat and rusticity to cultivation (Andrade et al. 2006, Capodifoglio et al. 2015).
However, recently, L. macrocephalus has also been reared in the State of Acre, in northern Brazil (Martins et al. 2017a, b).

As the State of Acre has great potential for fish farming, in 2015 there was the creation of a state industrial complex to produce fish native to Amazon, to intending boost the activity to around 2,162 fish farmers. Thus, in 2017, the State of Acre produced 8,000 tons of farmed fish, mainly native species, including $L$. macrocephalus. In 2018, this production had an increase of $6.3 \%$ and reached 8,500 tons (PeixeBR 2019). Despite the economic importance of $L$. macrocephalus for the fish farming in the State 
of Acre, little is known about its parasite fauna and epidemiological indices.

For L. macrocephalus farmed in the northeastern region of the State of São Paulo, the following parasites have been reported: Henneguya leporinicola Martins, Souza, Moraes \& Moraes, 1998 (Martins et al. 1999); Goezia leporini Martins \& Yoshitoshi 2003 (Martins \& Yoshitoshi 2003); Ichthyophthirius multifiliis Fouquet, 1876; Piscinoodinium pillulare (Schäperclaus, 1954) Lom, 1981; Henneguya piaractus Martins \& Souza, 1997; Myxobolus colossomatis Molnar \& Békési, 1993; Lernaea cyprinacea Linnaeus, 1758; Dolops carvalhoi Lemos de Castro, 1949; Trichodina sp., Epistylus sp., Argulus sp. and undetermined monogenean species (Martins et al. 2000, Tavares-Dias et al. 2001a, b, Martins et al. 2002, Schalch \& Moraes 2005). For L. macrocephalus of two fish farms in the municipality of Cruzeiro do Sul, in the State of Acre, parasitic infections have been caused by Jainus leporini Abdallah, Azevedo \& Luque, 2012; Urocleidoides paradoxus Kritsky, Thatcher \& Boeger, 1986; Urocleidoides eremitus Kritsky, Thatcher \& Boeger, 1986; Tereancistrum parvus Kritsky, Thatcher and Kayton, 1980; Kritskyia eirasi Guidelli, Takemoto \& Pavanelli, 2003; Tereancistrum paranaenses Karling, Lopes, Takemoto \& Pavanelli, 2014; Dactylogyridae spp., Microcotyle sp.; Prosthenhystera obesa Diesing, 1850; Procamallanus (Spirocamallanus) inopinatus Travassos, Artigas \& Pereira, 1928; Rhabdochona (Rhabdochona) acuminata Molin, 1860 and G. leporini (Martins et al. 2017a, b). Therefore, as there is no study on the parasite fauna of $L$. macrocephalus in the municipality of Rio Branco, the aim of this study was to investigate the metazoan parasites for this fish reared in four fish farms from this municipality.

\section{MATERIALS AND METHODS}

\section{Ethical disclosures}

This study was developed in accordance with the principles adopted by the Brazilian College of Animal Experimentation (COBEA), and authorization from Ethics Committee in the Use of Animal of the Embrapa Amapá (\#013/2018) was carried out.

From June 2015 to May 2017, 160 L. macrocephalus were collected in four fish farms (i.e., 40 specimens in each fish farm) in the municipality of Rio Branco, State of Acre (Brazil), for analysis of metazoan parasites. Each fish farm had different characteristics of management and structure (i.e., fish size, stocking density, sanitary quality, quality and source of water supply, etc.) (Table I). Fish from fish farm 1 were produced by the property, and the water supply of the tanks originates from the property. Fish from fish farms 2 and 3 were acquired from different suppliers of fingerlings, and the source of water supply for tanks in fish farm 2 is a river, but in fish farm 3 the source of water supply for tanks originates from the property. Fish from fish farm 4 were acquired from a supplier of fingerlings that made antiparasitic treatments using sodium chloride. The source of supply of the tanks of this fish farm originates from the property.

During fish collection, the $\mathrm{pH}$ was determined using a digital $\mathrm{pH}$ meter in each fish farm, as well as temperature (CDS107) and dissolved oxygen concentration, using a digital oximeter (HQ40D).

For each necropsied fish, we examined the mouth, opercula, gills, gastrointestinal tract and viscera. Gills were removed, fixed in 5\% formalin and analyzed using a stereomicroscope (SMZ $800 \mathrm{~N}$, Nikon, Tokyo, Japan) and microscope (Eclipse E100, Nikon, Tokyo, Japan). The gastrointestinal tract and viscera were removed and examined under a stereomicroscope for 
Table I. Localization, body parameters, stocking density and overall prevalence of parasites in Leporinus macrocephalus of four fish farms from Rio Branco, in State of Acre, western Amazon region (Brazil).

\begin{tabular}{|c|c|c|c|c|c|c|}
\hline Fish farms & $\begin{array}{c}\text { Geographical } \\
\text { coordinates }\end{array}$ & $\mathbf{N}$ & Weight (g) & Length (cm) & Density (fish/m²) & Prevalence (\%) \\
\hline 1 & $\begin{array}{c}9^{\circ} 55^{\prime} 05.70^{\prime \prime} \mathrm{S}- \\
67^{\circ} 47^{\prime} 01.46^{\prime \prime} \mathrm{W}\end{array}$ & 40 & $29.3 \pm 19.3$ & $9.9 \pm 2.3$ & 2.0 & 92.5 \\
\hline 2 & $\begin{array}{l}10^{\circ} 03^{\prime} 11.28^{\prime \prime} \mathrm{S}- \\
67^{\circ} 50^{\prime} 41.47^{\prime \prime} \mathrm{W}\end{array}$ & 40 & $90.0 \pm 27.9$ & $14.7 \pm 1.8$ & 2.5 & 72.5 \\
\hline 3 & $\begin{array}{l}9^{\circ} 45^{\prime} 24.5^{\prime \prime} \mathrm{S}- \\
68^{\circ} 04^{\prime} 25.0^{\prime \prime} \mathrm{W}\end{array}$ & 40 & $14.7 \pm 5.6$ & $8.0 \pm 0.9$ & 3.2 & 82.5 \\
\hline 4 & $\begin{array}{l}9^{\circ} 02^{\prime} 53.71^{\prime \prime} \mathrm{S}- \\
68^{\circ} 37^{\prime} 44.69^{\prime \prime} \mathrm{W}\end{array}$ & 40 & $5.1 \pm 207.8$ & $3.5 \pm 141.5$ & 2.5 & 0 \\
\hline
\end{tabular}

collection of endoparasites. The methodology used for collecting, fixing, counting and preparing the parasites for identification followed previous recommendations (Eiras et al. 2006).

The ecological terms used followed previous recommendations of Bush et al. (1997). The frequency of dominance (percentage of infracommunities in which a parasite species is numerically dominant) was determined (Rohde et al. 1995). The dispersion index (DI) and discrepancy index (D) were calculated using the Quantitative Parasitology 3.0 software, to detect the distribution pattern of parasite infracommunities (Rózsa et al. 2000), for species with prevalence $>10 \%$. The significance of $\mathrm{DI}$, for each intracommunity, was tested using the d-statistics (Ludwig \& Reynolds 1988).

Weight and total length of fish were used to calculate the relative condition factor $(\mathrm{Kn})$ of parasitized and non-parasitized fish (Le Cren 1951), which were compared using the Mann-Whitney $(U)$ test. The Spearman correlation coefficient (rs) was estimated to determine possible correlations between length and weight of host fish and the abundance of parasites (Zar 2010).

\section{RESULTS}

The specimens of $L$. macrocephalus examined had different body size due to the different stages of cultivation (fingerlings and fattening). Total parasite prevalence was high in fish farms 1-3 (Table I). In general, these fish farms had different management strategies and stocking density of L. macrocephalus and the size of this host.

In the four fish farms, $\mathrm{pH}$ and temperature were similar, but the levels of dissolved oxygen in water were low in fish farms 2-4 (Table II), which also had inadequate sanity conditions.

Monogeneans J. leporini occurred only in L. macrocephalus from fish farm 3, while $U$. paradoxus, U. eremitus only do not occurred in fish farm 4. However, T. parvus and R. (R.) acuminata occurred in fish from fish farms 1-3. Procamallanus (S.) inopinatus occurred in fish from fish farms 1 and 2, while Dolops discoidalis Bouvier, 1399 and Ergasilus sp. were found only in fish from fish farm 2 (Table III). In L. macrocephalus, the high infection levels were caused by $U$. paradoxus, U. eremitus and P. (S.) inopinatus, but the dominance was of $U$. paradoxus. The parasites presented an aggregated dispersion (Table IV).

There was a weak positive correlation between $U$. paradoxus abundance and the length ( $r s=0.25, p=0.001$ ) and weight ( $r s=0.24, p$ $=0.002$ ) of hosts, but no correlation between $U$. eremitus abundance and the length ( $r s=0.12, p=$ 0.13 ) and weight ( $r s=0.12, p=0.14$ ) was detected. 
Table II. Parameters of water quality in tanks of four fish farms of Leporinus macrocephalus from the Rio Branco, in State of Acre, western Amazon region (Brazil).

\begin{tabular}{|c|c|c|c|}
\hline Fish farms & Dissolved oxygen $(\mathbf{m g} / \mathbf{L})$ & $\mathbf{p H}$ & Temperature $\left({ }^{\circ} \mathbf{C}\right)$ \\
\hline 1 & $5.4 \pm 1.1$ & $7.7 \pm 1.2$. & $28.4 \pm 1.2$ \\
\hline 2 & $2.3 \pm 1.3$ & $5.6 \pm 1.2$ & $30.2 \pm 1.1$ \\
\hline 3 & $1.4 \pm 1.1$ & $5.1 \pm 1.1$ & $29.2 \pm 1.3$ \\
\hline 4 & $2.8 \pm 2.0$ & $5.9 \pm 0.6$ & $28.1 \pm 1.0$ \\
\hline
\end{tabular}

Positive correlation between $P$. (S) inopinatus abundance and the length ( $r s=0.55, p=<0.001$ ) and the weight ( $r s=0.55, p=<0.001$ ) of hosts was found.

There was no significant difference $(U=$ 2765.0, $p=0.37)$ in relative condition factor $(\mathrm{Kn})$ between parasitized $(\mathrm{Kn}=1.00 \pm 0.13, \mathrm{n}=99)$ and non-parasitized fish $(\mathrm{Kn}=1.03 \pm 0.38, \mathrm{n}=$ 61). The parasites abundance did not showed correlation ( $r s=-0.045, p=0.645$ ) with relative condition factor of hosts.

\section{DISCUSSION}

In L. macrocephalus of four fish farms from Rio Branco, State of Acre, the parasitic prevalence was $61.9 \%$. Similar prevalence was reported by Martins et al. (2017a) for this same fish cultured in thanks and dam in Cruzeiro do Sul, State of Acre. However, this was higher than the prevalence (21.3\%) reported by Martins et al. (2002) for $L$. macrocephalus from fish farms in the State of São Paulo. Half of the fish farms investigated here presented low levels of dissolved oxygen in water and the majority had inadequate sanity conditions, which favored the prevalence of parasites found. However, in the four fish farms studied, fish did not present macroscopic signals of diseases, due to low to moderate levels of parasitism. In general, the parasitism rate in $L$. macrocephalus has been attributed to stocking density and poor water quality, which favors the dissemination of infectious stages of parasites (Tavares-Dias et al. 2001a, b, Martins et al. 2002, 2017a). Also, U. paradoxus, U. eremitus and P. (S.) inopinatus were the parasites with higher prevalence in L. macrocephalus, and they showed a high aggregated dispersion, a pattern also found by Martins et al. (2017a) for this same host species. Aggregated dispersion of parasites has been attributed to genetic heterogeneity, exposure and susceptibility of the host population and local environmental factors (Tavares-Dias et al. 2015, Martins et al. 2017a).

The condition factor is a quantitative indicator of fish welfare that can be used as a tool for studying the relationship between host health status and parasitism (Le Cren 1951, Santos et al. 2013, Morey \& Arellano 2019). Thus, relative condition factor was used to evaluate the body condition in L. macrocephalus of the present study, and this was similar between parasitized and non-parasitized fish and no correlation between the parasitic load and relative condition factor was found, due to the moderate infection levels that not caused damages to the hosts. Similar results were reported for $L$. macrocephalus also infected by metazoan parasites found in the current study. Determining the factors that affect the presence of parasites is important to parasitology study. In fish populations, body size can influence parasite load (Santos et al. 2013, Martins et al. 2017a, Morey \& Arellano 2019); however, it 
Table III. Parasites in Leporinus macrocephalus of four fish farms from the Rio Branco, in State of Acre, western Amazon region (Brazil).

\begin{tabular}{|c|c|c|c|c|c|c|c|c|c|c|c|c|}
\hline Fish farms & \multicolumn{3}{|c|}{1} & \multicolumn{3}{|c|}{2} & \multicolumn{3}{|c|}{3} & \multicolumn{3}{|c|}{4} \\
\hline $\begin{array}{c}\text { Taxon/ species of } \\
\text { parasites }\end{array}$ & $\begin{array}{l}P \\
(\%)\end{array}$ & $\mathrm{Ml}$ & MA & $\begin{array}{c}P \\
(\%)\end{array}$ & $\mathrm{Ml}$ & MA & $\begin{array}{c}P \\
(\%)\end{array}$ & $\mathrm{Ml}$ & MA & $\begin{array}{c}P \\
(\%)\end{array}$ & $\mathrm{Ml}$ & MA \\
\hline \multicolumn{13}{|c|}{ Monogenea } \\
\hline Jainus leporini & 0 & 0 & 0 & 0 & 0 & 0 & 7.5 & 4.5 & 0.2 & 0 & 0 & 0 \\
\hline $\begin{array}{l}\text { Urocleidoides } \\
\text { paradoxus }\end{array}$ & 87.5 & 27.0 & 23.7 & 35.0 & 11.4 & 4.0 & 75.0 & 13.3 & 9.7 & 0 & 0 & 0 \\
\hline Urocleidoides eremitus & 25.0 & 12.2 & 3.0 & 22.5 & 8.2 & 1.8 & 52.5 & 10.2 & 5.1 & 0 & 0 & 0 \\
\hline Tereancistrum parvus & 15.0 & 25.0 & 3.7 & 2.5 & 2.0 & 0.05 & 12.5 & 4.2 & 0.4 & 0 & 0 & 0 \\
\hline \multicolumn{13}{|c|}{ Nematoda } \\
\hline $\begin{array}{c}\text { Procamallanus } \\
\text { (Spirocamallanus) } \\
\text { inopinatus }\end{array}$ & 32.5 & 2.0 & 0.67 & 62.5 & 2.4 & 1.5 & 0 & 0 & 0 & 0 & 0 & 0 \\
\hline $\begin{array}{l}\text { Rhabdochona } \\
\text { (Rhabdochona) } \\
\text { acuminata }\end{array}$ & 2.5 & 1.0 & 0.02 & 2.5 & 1.0 & 0.02 & 10.0 & 1 & 0.07 & 0 & 0 & 0 \\
\hline \multicolumn{13}{|c|}{ Crustacea } \\
\hline Dolops discoidalis & 0 & 0 & 0 & 22.5 & 5.2 & 1.2 & 0 & 0 & 0 & 0 & 0 & 0 \\
\hline Ergasilus sp. & 0 & 0 & 0 & 2.5 & 1 & 0.02 & 0 & 0 & 0 & 0 & 0 & 0 \\
\hline
\end{tabular}

P: Prevalence, MI: Mean intensity, MA: Mean abundance.

remains uncertain whether increased parasite presence is related to increased exposure time to parasites and their intermediate hosts due to the age of hosts, or due to greater surface area available for attachment due to the body size of hosts. However, distinguishing such effects can be very complicated since older fish are generally larger. There was a weak positive correlation between size (weight and length) of $L$. macrocephalus and the abundance of $U$. paradoxus, while the abundance of $P$. (S.) inopinatus presented positive correlation with the size of the host here examined. Martins et al. (2017a) also reported a positive correlation between the overall abundance of parasites and the weight and length of L. macrocephalus farmed in dam and tanks.

In L. macrocepahalus from four fish farms, only one fish farm did not have fish parasitized with monogeneans. Urocleidoides paradoxus, U. eremitus, J. leporini and T. parvus were found at similar infection levels among three fish farms. The infection levels by these monogeneans were similar to those reported by Martins et al. (2017a) for L. macrocephalus of intensive and extensive fish farm, but they were lower than the reported by Tavares-Dias et al. (2001b), for this same fish species from fish farms in the State of São Paulo. For L. macrocephalus from a fish farm in the State of Acre, 15 species of parasites 
Table IV. Parasites in Leporinus macrocephalus $(\mathrm{N}=160)$ of fish farms from the Rio Branco, in State of Acre, western Amazon region (Brazil).

\begin{tabular}{|c|c|c|c|c|c|c|c|c|c|}
\hline Species of parasites & SI & EF/PF & P (\%) & MI & MA & FD (\%) & ID & d & D \\
\hline $\begin{array}{c}\text { Jainus leporini } \\
\begin{array}{c}\text { Urocleidoides } \\
\text { paradoxus }\end{array}\end{array}$ & Gills & $160 / 02$ & 1.25 & 4.5 & 0.05 & 0.4 & - & - & - \\
\hline $\begin{array}{c}\text { Urocleidoides } \\
\text { eremitus }\end{array}$ & Gills & $160 / 78$ & 48.7 & 19.1 & 9.3 & 67.5 & 6.175 & 36.5 & 0.672 \\
\hline $\begin{array}{c}\text { Tereancistrum } \\
\text { parvus }\end{array}$ & Gills & $160 / 11$ & 6.8 & 15.3 & 1.0 & 7.6 & - & - & - \\
\hline $\begin{array}{c}\text { Procamallanus (S.) } \\
\text { inopinatus }\end{array}$ & Intestine & $160 / 38$ & 23.7 & 2.3 & 0.5 & 3.9 & 2.064 & 17.8 & 0.823 \\
\hline $\begin{array}{c}\text { Rhabdochona (R.) } \\
\text { acuminata }\end{array}$ & Intestine & $160 / 5$ & 3.1 & 1 & 0.03 & 0.2 & - & - & - \\
\hline $\begin{array}{c}\text { Dolops discoidalis } \\
\text { Tegument }\end{array}$ & $160 / 9$ & 5.6 & 5.2 & 0.2 & 2.1 & - & - & - \\
\hline Ergasilus sp. & Gills & $160 / 1$ & 0.6 & 1 & 0.006 & 0.05 & - & - & - \\
\hline
\end{tabular}

SI: Site of infection, EF: Examined fish, PF: Parasitized fish, ID: Index of dispersion, d: statistic-d, D: Discrepancy, P: Prevalence, MA: Mean abundance, MI: Mean intensity.

were reported (Martins et al. 2017a) and five of these parasite species were also found in the present study. Also, L. macrocephalus from fish farm 4 was represented by fingerlings recently purchased for fattening. Therefore, these fish did not have time to re-infect themselves in the fish farm and also acquired other parasite species.

Larvae of P. (S.) inopinatus have copepods as intermediate hosts and are ingested by fish, which are the definitive hosts of this nematode, an endoparasite frequent in wild fish that can also infect farmed fish (Hamann 1999, Martins et al. 2017a, Neves et al. 2020). Thus, this endoparasite occurred only in L. macrocephalus from two fish farms and at similar infection levels. However, the infection levels were lower than those reported for this same fish in tanks and dam in the State of Acre (Martins et al. 2017a). Rhabdochona (R.) acuminata occurred only in two fish farms, and at low and similar infection levels. As Rhabdochona species have as main intermediate hosts mayflies (Ephemeroptera), and less often some other aquatic insects, such as Trichoptera or Plecoptera (Moravec 2010), hence intermediate hosts containing infective stages of $R$. (R.) acuminata seem is present only in two fish farms. Therefore, the infection levels by both nematode species are highly dependent on the presence of intermediate hosts in the environment. Also, Martins et al. (2017b) reported that both nematode species have seasonal variation in L. macrocephalus.

Parasitic crustaceans such as Argulidae and Copepoda are components of the communities of ectoparasites in Brazilian freshwater fish and occur in several host species of several taxonomic groups (Tavares-Dias et al. 2015). However, details of the life history for most of the parasitic crustaceans of fish remain unknown. Dolops discoidalis is an argulid that infests diverse fish species, because it has low host specificity (Tavares-Dias et al. 2015, Morey \& Arellano 2019). Among Ergasilidae, species of the genus Ergasilus have preference for the gills of hosts (Tavares-Dias et al. 2015), as occurred in L. macrocephalus in the current study. In 
Brazil, around 17 species of Ergasilus are known and these occur most frequently in hosts from the Amazon region (Tavares-Dias et al. 2015). Leporinus macrocephalus was infested with D. discoidalis and Ergasilus sp. and at low parasitism levels. In contrast, Martins et al. (2017a) have not reported infestation with parasitic crustaceans in L. macrocephalus farmed in the State of Acre. In L. macrocephalus farmed in the State of São Paulo, the infestations by crustaceans were mainly caused by L. cyprinacea, a common lernaeid of farmed fish in the Southeast region of Brazil (Martins et al. 2000, 2002, Tavares-Dias et al. 2001b, Schalch \& Moraes 2005). Therefore, these results indicate differences in the parasitic crustacean fauna for L. macrocephalus among Brazilian regions.

\section{CONCLUSIONS}

For L. macrocephalus, the parasite community was composed of species of monogeneans, nematodes and crustaceans, parasites with low to moderate infection levels and aggregated dispersion. The parasitism was influenced by the different management strategies of fish farms, mainly to the stocking density of $L$. macrocephalus and the size of this host, as well as by the oxygen levels in water, which varied among the fish farms. As expected, there was a low diversity of endoparasites, which depend on the presence of intermediate hosts with infective stages to maintain their complex life cycle. This was the first report of $D$. discoidalis and Ergasilus sp. for L. macrocephalus. Lastly, it was the second report of $P$. (S.) inopinatus and $R$. (R.) acuminata for L. macrocephalus.

\section{Acknowledgments}

Tavares-Dias, M. was supported by a researcher fellowship of the Conselho Nacional de Desenvolvimento Científico e Tecnológico (CNPq, Brazil) (\# 303013/2015-0). Neves,
LR Pereira was supported by a Doctoral fellowship form Programa Nacional de Pós-Doutorado-Coordenação de Aperfeiçoamento de Pessoal de Nivel Superior (CAPES, Brazil).

\section{REFERENCES}

ANDRADE LS, HAYASHI C \& SOARES CM. 2006. Refúgios artificiais coloridos e o desempenho e sobrevivência de alevinos de Leporinus macrocephalus (Garavello \& Britsky, 1988). Ciên Rural 36(1): 247-251.

BUSH AO, LAFFERTY KD, LOTZ JM \& SHOSTAK AW. 1997. Parasitology meets ecology on its own terms. J Parasitol 83: 575-583.

CAPODIFOGLIO KRH, ADRIANO EA, SILVA MRM \& MAIA AAM. 2015. Supplementary data of Henneguya leporinicola (Myxozoa, Myxosporea) a parasite of Leporinus macrocephalus from fish farms in the state of Sao Paulo, Brazil. Acta Parasitol 60(3): 451-458.

EIRAS JC, TAKEMOTO RM \& PAVANELLI GC. 2006. Métodos de estudos e técnicas laboratoriais em parasitologia de peixes. Maringá: Eduem, 199 p.

HAMANN MI. 1999. Population biology of Spirocamallanus inopinatus (Travassos, Artigas et Pereira, 1928) Nematoda: Camallanidae) in Serrasalmus spiropleura Kner, 1860 (Pisces: Characidae) from Corrientes, Argentina. Res Parasitol 59(1-2): 1-6.

LE CREN ED. 1951. The length-weight relationship and seasonal cycle in gonad weight and condition in the perch (Perca fluviatilis). J Anim Ecol 20: 201-219.

MARTINS ML, MORAES FR, FUJIMOTO RY, ONAKA EM, NOMURA DT, SILVA, CAH \& SCHALCH SHC. 2000. Parasitic infections in cultivated freshwater fishes: a survey of diagnosticated cases from 1993 to 1998. Rev Bras Parasitol Vet 9: 23-28.

MARTINS ML, ONAKA EM, MORAES FR, BOZZO FR, MELLO-FARO A, PAIVA C \& GONÇALVES A. 2002. Recent studies on parasitic infections of freshwater cultivated fish in the state of São Paulo, Brazil. Acta Scientiarum 24(4): 981-985.

MARTINS ML, SOUZA VN, MORAES JRE \& MORAES FR. 1999. Infecção branquial de Leporinus macrocephalus Garavello \& Britski, 1988 (Osteichthyes: Anostomidae) por Henneguya leporinicola n. sp. (Myxozoa: Myxobolidae). Descrição, histopatologia e tratamento. Rev Bras Biol 59(3): 527-534.

MARTINS ML \& YOSHITOSHI ER. 2003. A new nematode species Goezia leporini n. sp. (Ascaridoidea) from 
cultivated freshwater fish Leporinus macrocephalus (Anostomidae) in Brazil. Braz J Biol 63: 497-506.

MARTINS WMO, JUSTO MCN, CÁRDENAS MQ \& COHEN SC. 2017a. Metazoan parasite communities of Leporinus macrocephalus (Characiformes: Anostomidae) in cultivation systems in the western Amazon, Brazil. Acta Amaz 47(4): 301-310.

MARTINS WMO, JUSTO MCN, CÁRDENAS MQ \& COHEN SC. 2017b. Seasonality of parasitic helminths of Leporinus macrocephalus and their parasitism rates in farming systems in the Amazon. Braz. J Vet Parasitol 26(4): 419-426.

MORAVEC F. 2010. Some aspects of the taxonomy, biology, possible evolution and biogeography of nematodes of the spirurine genus Rhabdochona Railliet, 1916 (Rhabdochonidae, Thelazioidea). Acta Parasitol 55(2): 144-160

MOREY GAM \& ARELLANO HS. 2019. Infestation of Dolops discoidalis Bouvier, 1899 (Branchiura: Argulidae) on Pseudoplatystoma punctifer (Castelnau, 1855) (Siluriformes: Pimelodidae) from a fish pond in the Peruvian Amazon. Aquaculture 500: 414-416.

NEVES LR, ABDON SILVA LM, FLORENTINO AC \& TAVARESDIAS M. 2020. Distribution patterns of Procamallanus (Spirocamallanus) inopinatus (Nematoda: Camallanidae) and its interactions with freshwater fish in Brazil. Braz J Vet Parasitol 29(4): e012820.

PEIXEBR - ASSOCIAÇÃO BRASILEIRA DA PISCICULTURA. 2019. Anuário PeixeBR da piscicultura 2019. https://www. peixebr.com.br/anuario-peixe-br-da-piscicultura-2019/.

ROHDE K, HAYWARD C \& HEAP M. 1995. Aspects of the ecology of metazoan ectoparasites of marine fishes. Int J Parasitol 25: 945-970.

RÓZSA L, REICZIGEL J \& MAJOROS G. 2000. Quantifying parasites in samples of hosts. J Parasitol 86: 228-232.

SANTOS EF, TAVARES-DIAS M, PINHEIRO DA, NEVES LR, MARINHO RGB \& DIAS MKR. 2013. Fauna parasitária de tambaqui Colossoma macropomum (Characidae) cultivado em tanque-rede no estado do Amapá, Amazônia oriental. Acta Amaz 43: 107-114.

SCHALCH SHC \& MORAES FR. 2005. Distribuição sazonal de parasitos branquiais em diferentes espécies de peixes em pesque-pague do município de Guariba - SP, Brasil. Rev Bras Parasitol Vet 14: 141-146.

TAVARES-DIAS M, DIAS-JUNIOR MBF, FLORENTINO AC, SILVA MA \& CUNHA AC. 2015. Distribution pattern of crustacean ectoparasites of freshwater fish from Brazil. Rev Brasil Parasitol Vet 24(2): 136-147.
TAVARES-DIAS M, MARTINS ML \& MORAES FR. 2001a. Fauna parasitária de peixes oriundos de pesque-pague do município de Franca, São Paulo, Brasil. I. Protozoários. Rev Bras Zool 18(1): 67-79.

TAVARES-DIAS M, MORAES FR, MARTINS ML \& KRONKA SN. 2001b. Fauna parasitária de peixes oriundos de pesquepagues do município de Franca, São Paulo, Brasil. II. Metazoários. Rev Bras Zool 18(1): 81-95.

ZAR JH. 2010. Biostatistical analysis. $5^{\text {th }}$ ed. New Jersey: Prentice-Hall, $944 \mathrm{p}$.

\section{How to cite}

NEGREIROS LP, NEVES LR, TAVARES-DIAS M. 2021. Parasites in Leporinus macrocephalus (Anostomidae) of four fish farms from the western Amazon (Brazil). An Acad Bras Cienc 93: e20190988. DOI 10.1590/00013765202120190988.

Manuscript received on August 23, 2019;

accepted for publication on April 19, 2020

\section{LUCIANO P. NEGREIROS 1}

https://orcid.org/0000-0002-5771-8289

\section{LIGIA R. NEVES ${ }^{2}$}

https://orcid.org/0000-0002-7061-6973

\section{MARCOS TAVARES-DIAS ${ }^{2,3}$}

https://orcid.org/0000-0002-8376-1846

${ }^{1}$ Instituto Federal de Educação, Ciências e Tecnologia do Acre/IFAC, Avenida Brasil, 920, Xavier Maia, 69903-068 Rio Branco, AC, Brazil

2 Programa de Pós-Graduação em Biodiversidade e Biotecnologia/Bionorte, Universidade Federal do Amapá/UNIFAP, Rodovia Juscelino Kubitschek, s/n, Universidade, 68903-419 Macapá, AP, Brazil

${ }^{3}$ Embrapa Amapá, Rodovia Juscelino Kubitschek, Km 5 , 2600, Universidade, 68903-419 Macapá, AP, Brazil

Correspondence to: Marcos Tavares-Dias

E-mail:marcos.tavares@embrapa.br

\section{Author contributions}

LUCIANO P. NEGREIROS contributed with the data collection and text elaboration, LIGIA R. NEVES contributed with the fish and data collection and MARCOS TAVARES-DIAS was the coordinator of this work.

\section{(cc) BY}

